would be useful for discriminating between the influence of CD34 $4^{+}$cells and that of neovascularization on the overall neurogenic capacity of the dentate gyrus and forebrain SVZ. It may also provide insight into the possibility of recruiting neural stem cells from these regions for brain repair. This information would be particularly relevant in regard to the experimental group that also received erythropoietin, as this treatment has been shown to enhance both angiogenesis and neurogenesis (13). The current study suggests that one mechanism accounting for the functional recovery resulting from cord blood cell delivery works through the enhancement of angiogenesis around the site of degeneration. This finding provides a note of optimism for developing therapeutic strategies for stroke. Taguchi et al. provide an important piece of the puzzle, but there remains much to be determined about the mechanisms involved and the specific role of neurogenesis in brain recovery from stroke before a comprehensive picture will emerge on how to treat this old problem (17).

\section{Acknowledgments}

The author's research is supported in part by NIH grants AG20047 and AG22555.

Address correspondence to: Daniel A. Peterson, Department of Neuroscience,
The Chicago Medical School at Rosalind Franklin University of Medicine and Science, 3333 Green Bay Road, North Chicago, Illinois 60064, USA. Phone: (847) 578-3411; Fax: (847) 578-8545; E-mail: daniel.peterson@rosalindfranklin.edu.

1. Hallbergson, A.F., Gnatenco, C., and Peterson, D.A. 2003. Neurogenesis and brain injury: managing a renewable resource for repair. J. Clin. Invest. 112:1128-1133. doi:10.1172/JCI200320098.

2. Gould, E., Vail, N., Wagers, M., and Gross, C.G. 2001. Adult-generated hippocampal and neocortical neurons in macaques have a transient existence. Proc. Natl. Acad. Sci. U. S. A. 98:10910-10917.

3. Zhao, M., et al. 2003. Evidence for neurogenesis in the adult mammalian substantia nigra. Proc. Natl. Acad. Sci. U. S. A. 100:7925-7930.

4. Markakis, E.A., Palmer, T.D., Randolph-Moore, L., Rakic, P., and Gage, F.H. 2004. Novel neuronal phenotypes from neural progenitor cells. J. Neurosci. 24:2886-2897.

5. Kornack, D.R., and Rakic, P. 2001. Cell proliferation without neurogenesis in adult primate neocortex. Science. 294:2127-2130.

6. Sanai, N., et al. 2004. Unique astrocyte ribbon in adult human brain contains neural stem cells but lacks chain migration. Nature. 427:740-744.

7. Palmer, T.D., Markakis, E.A., Willhoite, A.R., Safar, F., and Gage, F.H. 1999. Fibroblast growth factor-2 activates a latent neurogenic program in neural stem cells from diverse regions of the adult CNS. J. Neurosci. 19:8487-8497.

8. Nunes, M.C., et al. 2003. Identification and isolation of multipotential neural progenitor cells from the subcortical white matter of the adult human brain. Nat. Med. 9:439-447.

9. Belachew, S., et al. 2003. Postnatal NG2 proteoglycan-expressing progenitor cells are intrinsically multipotent and generate functional neurons. J. Cell Biol. 161:169-186.

10. Peterson, D.A. 2002. Stem cells in brain plasticity and repair. Curr. Opin. Pharmacol. 2:34-42.

11. Pencea, V., Bingaman, K.D., Wiegand, S.J., and Luskin, M.B. 2001. Infusion of brain-derived neurotrophic factor into the lateral ventricle of the adult rat leads to new neurons in the parenchyma of the striatum, septum, thalamus, and hypothalamus. J. Neurosci. 21:6706-6717.

12. Yoshimura, S., et al. 2001. FGF-2 regulation of neurogenesis in adult hippocampus after brain injury. Proc. Natl. Acad. Sci. U. S. A. 98:5874-5879.

13. Shingo, T., Sorokan, S.T., Shimazaki, T., and Weiss, S. 2001. Erythropoietin regulates the in vitro and in vivo production of neuronal progenitors by mammalian forebrain neural stem cells. J. Neurosci. 21:9733-9743.

14. Yoshimura, S., et al. 2003. FGF-2 regulates neurogenesis and degeneration in the dentate gyrus after traumatic brain injury in mice. J. Clin. Invest. 112:1202-1210. doi:10.1172/JCI200316618.

15. Nakatomi, H., et al. 2002. Regeneration of hippocampal pyramidal neurons after ischemic brain injury by recruitment of endogenous neural progenitors. Cell. 110:429-441.

16. Kokaia, Z. and Lindvall, O. 2003. Neurogenesis after ischaemic brain insults. Curr. Opin. Neurobiol. 13:127-132.

17. Taguchi, A., et al. 2004. Administration of CD34+ cells after stroke enhances neurogenesis via angiogenesis in a mouse model. J. Clin. Invest. 114:330-338. doi:10.1172/JCI200420622.

18. Chen, J., et al. 2001. Intravenous administration of human umbilical cord blood reduces behavioral deficits after stroke in rats. Stroke. 32:2682-2688.

19. Willing, A.E., et al. 2003. Intravenous versus intrastriatal cord blood administration in a rodent model of stroke. J. Neurosci. Res. 73:296-307.

20. Saporta, S., et al. 2003. Human umbilical cord blood stem cells infusion in spinal cord injury: engraftment and beneficial influence on behavior. J. Hematother. Stem Cell Res. 12:271-278.

\title{
Unlocking the secrets of the pancreatic $\beta$ cell: man and mouse provide the key
}

\author{
Andrew T. Hattersley \\ Diabetes and Vascular Medicine, Institute of Biomedical and Clinical Science, Peninsula Medical School, Exeter, United Kingdom.
}

\begin{abstract}
Failure of the pancreas to secrete sufficient insulin results in type 2 diabetes, but the pathogenesis of pancreatic $\beta$ cell dysfunction is still poorly understood. New insights into $\beta$ cell failure come from defining the genes involved in rare genetic subtypes of diabetes and creating appropriate animal models. A new mouse model of transient neonatal diabetes mellitus emphasizes that both the number of $\beta$ cells and their function are critical for insulin secretion and may be regulated by imprinted genes (see the related article beginning on page 339).
\end{abstract}

Nonstandard abbreviations used: hydatidiform mole-associated and -imprinted transcript (HYMAI); P1-derived artificial chromosome (PAC); transient neonatal diabetes mellitus (TNDM); type 2 diabetes (T2D); $\underline{Z}$ finger protein that regulates apoptosis and cell cycle arrest $(Z A C)$.

Conflict of interest: The author has declared that no conflict of interest exists.

Citation for this article: J. Clin. Invest. 114:314-316 (2004). doi:10.1172/JCI200422506.
The regulated secretion of insulin by the pancreatic $\beta$ cell maintains blood sugar concentrations within a narrow physiological range. In over 150 million people worldwide, however, pancreatic $\beta$ cells fail to secrete adequate insulin, usually in the presence of increased insulin resistance, which results in type 2 diabetes (T2D). Understanding the pathways that result in $\beta$ cell dysfunction at a physiological and molecular level is critical for improved understanding and treatment of T2D.

\section{Learning from rare genetic subtypes of diabetes}

How can we study the pancreatic $\beta$ cell in humans when these cells are not readily accessible? Accidents of nature in which a single gene defect results in severe $\beta$ cell dysfunction, causing diabetes, offer the chance of gaining new insights into this disease if the responsible gene can be defined. The best example of such research has been the use of positional cloning to demonstrate that heterozygous mutations of the genes encoding the hepatic transcription factors 
Table 1

Comparison of the clinical features and pathophysiology related to glucose regulation in human TNDM with the transgenic mouse model, TNDM29

\begin{tabular}{|c|c|c|c|c|}
\hline Human TNDM & In utero & Neonatal (0-3 mo) & $\begin{array}{l}\text { Early childhood } \\
(0.5-4 \mathrm{yr})\end{array}$ & $\begin{array}{l}\text { Late childhood/ } \\
\text { adolescence/early } \\
\text { adulthood (4-25 yr) }\end{array}$ \\
\hline Phase of the disease & & Neonatal diabetes & Apparent remission & Relapse of diabetes \\
\hline Features in humans & $\begin{array}{l}\text { Greatly reduced growth in } \\
\text { utero; birth weight typically } \\
\text { less than } 2 \text { nd percentile }\end{array}$ & $\begin{array}{l}\text { Marked hyperglycemia (>20 } \\
\text { mmol/l) usually diagnosed } \\
\text { in first week of life } \\
\text { Needs insulin treatment } \\
\text { Reduction in insulin dose } \\
\text { during infancy typically } \\
\text { discontinued at } 3 \text { months }\end{array}$ & Normal glucose tolerance & $\begin{array}{l}\approx 2 / 3 \text { of individuals develop } \\
\text { diabetes with some residual } \\
\text { endogenous insulin } \\
\text { secretion } \\
\text { Mean age of diagnosis } \\
\text { is } 14 \text { years (range, } 4-25 \text { ) }\end{array}$ \\
\hline Pathophysiology in humans & $\begin{array}{l}\text { Probable insulin deficiency } \\
\text { in utero reduces } \\
\text { insulin-mediated growth }\end{array}$ & $\begin{array}{l}\text { Marked insulin deficiency } \\
\text { at birth } \\
\text { Subsequent progressive } \\
\text { improvement in endogenous } \\
\text { insulin secretion }\end{array}$ & Normal insulin secretion & $\begin{array}{l}\text { Loss of first phase insulin } \\
\text { secretion (as seen in type } 2 \\
\text { diabetes) }\end{array}$ \\
\hline TNDM29 mouse & $\begin{array}{l}\text { Embryonic (day } 14.5 \\
\text { after conception) }\end{array}$ & Neonate (days 2-8) & Juvenile (1.5-2 mo) & Adult (6-10 mo) \\
\hline Features in mouse & $\begin{array}{l}\text { Impairment of development } \\
\text { of all pancreatic endocrine } \\
\text { cell types } \\
\text { Birth weight normal }\end{array}$ & $\begin{array}{l}\text { Hyperglycemia during both } \\
\text { fasting and after glucose } \\
\text { challenge }\end{array}$ & Normal glucose tolerance & $\begin{array}{l}\text { Normal fasting but } \\
\text { hyperglycemia after glucose } \\
\text { challenge }\end{array}$ \\
\hline Pathophysiology in mouse & $\begin{array}{l}\text { Reduced levels of } \\
\text { transcription factors: } \\
\text { Pdx1, Ngn3, Pax6 }\end{array}$ & $\begin{array}{l}\beta \text { cell dysfunction } \\
\text { Insulin secretion reduced } \\
\text { relative to hyperglycemia }\end{array}$ & Normal insulin secretion & $\begin{array}{l}\beta \text { cell dysfunction } \\
\text { Reduced insulin secretion } \\
\text { with glucose challenge }\end{array}$ \\
\hline$\beta$ cell mass relative to WT & $\begin{array}{l}\text { Reduced } \sim 2 \text {-fold; } \\
\text { reduced } \beta \text { cell number }\end{array}$ & Similar to WT & $\begin{array}{l}\approx 2 \text {-fold increase in } \beta \text { cell } \\
\text { number }\end{array}$ & Similar \\
\hline $\begin{array}{l}\text { Total insulin content of } \\
\text { pancreas relative to WT }\end{array}$ & & Reduced & Similar to WT & Similar \\
\hline $\begin{array}{l}\text { Possible synthesis of } \\
\text { findings }\end{array}$ & $\begin{array}{l}\text { Reduced development of } \\
\text { all endocrine cells including } \\
\beta \text { cells }\end{array}$ & $\begin{array}{l}\text { Compensatory increase in } \beta \\
\text { cell number begins but is not } \\
\text { adequate, as insulin synthesis } \\
\text { is reduced and secretion is } \\
\text { abnormal despite normal } \\
\beta \text { cell mass }\end{array}$ & $\begin{array}{l}\text { Increased } \beta \text { cell mass } \\
\text { compensates for reduced } \\
\text { insulin synthesis and } \\
\text { secretion }\end{array}$ & $\begin{array}{l}\text { Compensatory increase in } \beta \\
\text { cell mass is not maintained, } \\
\text { which results in reduced } \\
\beta \text { cell function }\end{array}$ \\
\hline
\end{tabular}

HNF- $1 \alpha$ and HNF- $4 \alpha$ cause early-onset diabetes $(1,2)$. Subsequent studies have allowed the unraveling of a previously unexpected transcription factor network that is crucial to the maintenance of normal $\beta$ cell development and function (3) and also involved in the susceptibility to T2D $(4,5)$. Although genetics provided the initial breakthrough, subsequent careful animal and molecular biological studies were needed to elucidate the underlying mechanism.

\section{Transient neonatal diabetes:} a disorder of imprinting in humans

Now, studies of the molecular genetics of transient neonatal diabetes mel- litus (TNDM) in humans and mice have been combined to give new insights into the development and physiology of the $\beta$ cell. TNDM is a rare condition (affecting approximately 1 in 600,000 live births) that is characterized by a unique clinical course (6). Affected babies have low birth weight, and high blood-glucose values are detected in the first week of life - features of low pancreatic insulin secretion in utero and after delivery, respectively. Initially, insulin treatment is needed, but by 12 weeks, endogenous insulin secretion has usually improved sufficiently to allow its discontinuation. Patients remain in apparent remission for many years, but $2 / 3$ of them will subsequently develop diabetes, usually in adolescence. Their diabetes at this stage, despite their age and lack of obesity, is similar to T2D, with a loss of firstphase insulin secretion (7).

The first major clue to the etiology of this disappearing and reappearing diabetes came from genetic analysis implicating abnormalities of an imprinted locus on chromosome 6 (8). Three interrelated genetic mechanisms have been found to cause most TNDM (reviewed in ref. 6): (a) inheriting 2 copies of the paternal chromosome 6 (paternal uniparental isodisomy of chromosome 6); (b) paternally inheriting a duplication of $6 \mathrm{q} 24$; or (c) a mater- 
nal methylation defect within this region. These data are consistent with TNDM resulting from biallelic expression rather than the normal paternal monoallelic expression that results from methylation and hence inactivation of the maternally inherited allele. There are 2 overlapping imprinted genes with maternal allele silencing in the TNDM locus: $Z A C$ ( $\underline{Z}$ finger protein that regulates apoptosis and cell cycle arrest) and HYMAI (hydatidiform mole-associated and -imprinted transcript) (9). Overexpression of one or both of these genes could be responsible for the TNDM phenotype.

\section{New insights from the mouse model TNDM29}

This genetic information has allowed an excellent rodent model of TNDM to be created. Ma and colleagues, in this issue of the JCI (10), describe a transgenic mouse (TNDM29) with overexpression of a P1derived artificial chromosome (PAC) containing the complete $Z A C$ and HYMAI human genes. In keeping with the observation that TNDM in humans only results from the paternal inheritance of the duplication of $6 \mathrm{q} 24$, offspring generated by paternal transmission of the overexpressing PAC, but not maternal transmission, were hyperglycemic as neonates. The glycemia changes in TNDM29 mice mirrors those in TNDM in humans, with remission and normal glucose tolerance in juvenile mice followed by relapse and glucose intolerance in adulthood (Table 1).

The initial studies of the TNDM29 transgenic mice have already suggested possible underlying mechanisms for the recurring $\beta$ cell failure. The most fascinating findings in the TNDM model are the marked changes in $\beta$ cell number compared with wild-type mice and the relationship of these changes in $\beta$ cell number to the varying glucose tolerance and insulin secretion (Table 1). In the pancreata of the early embryonic TNDM29 transgenic mice, there was a marked reduction in the number of $\beta$ and other pancreatic endocrine cells. This effect was probably mediated, at least partially, by downregulation of critical pancreatic transcription factors Pdx1, Ngn3, and Pax6. In late gestation and early postnatal life, there was a rapid increase in pancreatic $\beta$ cell mass in the TNDM29 mouse, achieved primarily by an increased number of $\beta$ cells (either through increased proliferation or decreased apoptosis), which help at least in part to compensate for the low initial number of $\beta$ cells. Despite this, in the early neonate, the total insulin content of the pancreas was still reduced, and the animal was hyperglycemic as a result of inadequate insulin secretion. The number of $\beta$ cells continued to increase and by $2-3$ months (juvenile) was approximately twice the number observed in wild-type mice, although the total insulin content of the pancreas was unchanged, which suggests that each $\beta$ cell contains less insulin. The increased number of $\beta$ cells enabled normal glucose tolerance. However, the compensatory increase in $\beta$ cell mass was not maintained, and adult TNDM29 mice had a $\beta$ cell mass similar to that in wild-type animals. The glucose tolerance of the adult animals deteriorated and was characterized by reduced early insulin secretion. A key result is that disordered imprinting, like mutations in transcription factors (4), has led to both altered development and altered function of $\beta$ cells.

\section{New directions}

As with all good science, these studies have raised more questions than they have answered. Why is the insulin deficiency less severe in mouse than human? Does the phenotype result only from the overexpression of $Z A C$, a potent cell cycle regulator, or is increased expression of $H Y M A I$ - an apparently untranslated mRNA of unknown function - also needed? Does the rapid increase in $\beta$ cell mass in late intrauterine and early postnatal life represent secondary compensatory mechanisms, or is it directly mediated by $Z A C / H Y M A I$ ? Is it the failure of $\beta$ cell function as an adult a consequence of rapid compensation in early life? If the latter scenario is true, there could be parallels with fetal exposure to hyperglycemia in utero resulting in glucose intolerance as an adult. Again, the combination of human genetics and a resultant mouse model offers the opportunity for discovery of many more of the secrets of the pancreatic $\beta$ cell.

\section{Acknowledgments}

Andrew Hattersley is a Wellcome Trust research leave fellow.

Address correspondence to: Andrew T. Hattersley, Diabetes and Vascular Medicine, Institute of Biomedical and Clinical Science, Peninsula Medical School, Barrack Road, Exeter, EX2 5AX, United Kingdom. Phone: 44-1392-403089; Fax: 44-1392403027; E-mail: A.T.Hattersley@ex.ac.uk.

1. Yamagata, K., et al. 1996. Mutations in the hepatic nuclear factor 1 alpha gene in maturity-onset diabetes of the young (MODY3). Nature. 384:455-458.

2. Yamagata, K., et al. 1996. Mutations in the hepatocyte nuclear factor 4 alpha gene in maturity-onset diabetes of the young (MODY1). Nature. 384:458-460.

3. Servitja, J.M., and Ferrer, J. 2004. Transcriptional networks controlling pancreatic development and beta cell function (review). Diabetologia. 47:597-613.

4. Silander, K., et al. 2004. Genetic variation near the hepatocyte nuclear factor- 4 alpha gene predicts susceptibility to type 2 diabetes. Diabetes. 53:1141-1149.

5. Love-Gregory, L.D., et al. 2004. A common polymorphism in the upstream promoter region of the hepatocyte nuclear factor- 4 alpha gene on chromosome $20 \mathrm{q}$ is associated with type 2 diabetes and appears to contribute to the evidence for linkage in an Ashkenazi Jewish population. Diabetes. 53:1134-1140.

6. Temple, I.K., and Shield, J.P. 2002. Transient neonatal diabetes, a disorder of imprinting. J. Med. Genet. 39:872-875.

7. Shield, J.P., et al. 2001. Variable evidence of pancreatic insufficiency in those children with transient neonatal diabetes in remission [abstract]. Pediatr. Res. 49:P2-619.

8. Temple, I.K., et al. 1995. An imprinted gene(s) for diabetes? Nat. Genet. 9:110-112.

9. Kamiya, M., et al. 2000. The cell cycle control gene ZAC/PLAGL1 is imprinted--a strong candidate gene for transient neonatal diabetes. Hum. Mol. Genet. 9:453-460.

10. Ma, D., et al. 2004. Impaired glucose homeostasis in transgenic mice expressing the human transient neonatal diabetes mellitus locus, TNDM. J. Clin. Invest. 114:339-348. doi:10.1172/JCI200419876. 